\title{
Wild strains of fermenting yeast isolated of sugar cane juice from an alcohol distillery from Mato Grosso, Brazil
}

\author{
Rosimeire Oenning da Silva ${ }^{1,2}$, Margareth Batistote ${ }^{3}$ and Marney Pascoli Cereda ${ }^{4 *}$ \\ ${ }^{1,2}$ Master Program of Biotechnology; Catholic University of Campo Grande - UCDB; 79117-900; Campo Grande - \\ MS - Brasil. ${ }^{2,3}$ State University of Mato Grosso - UNEMAT; 78390-000; Barra dos Bugres - MT - Brasil. ${ }^{3}$ State \\ University of Mato Grosso do Sul - UEMS; CEP: 79.730-000; Gloria de Dourados - MS - Brasil. ${ }^{4}$ Master Program \\ of Biotechnology and CeTeAgro - Center of Technology and Agribusiness Analysis, Catholic University of Campo \\ Grande - UCDB; 79117-900; Campo Grande - MS - Brasil.
}

\begin{abstract}
Ethanol production for fuel is important for the Brazilian economy as a renewable solution to oil derivatives. The industrial process uses commercially available yeast, most of them isolated from sugar mills from the Brazilian state of São Paulo. The research information on the availability of yeast appropriate to the climatic conditions occurring in the Midwest region of Brazil is scarce. The article presents the isolation and morphological characterization of fermentative wild yeast prospected on the sugar cane juice of a sugar and alcohol mill of Mato Grosso State. The juice samples were collected in both the hot and rainy $(H R)$ season and in the cold and dry (CD) one. The diluted sugar cane juice samples were plated on agar LWYN and evaluated for fermentation in test tubes containing inverted Durham tubes. From 26 morphotypes isolated, 50\% were able to ferment sugar cane juice. Greater number and diversity of yeasts was found in both December $(H R)$ and July (CD). In the remaining months of each season there were a low number of colonies with a poor diversity.
\end{abstract}

Key words: Isolation, morphology, bioprospecting, biodiversity, fermentation

\section{INTRODUCTION}

The ethanol for fuel is renewable, cheaper and less polluting them the oil. The yeast plays a very important role in their production by fermentation. In biotechnological processes, the bioprospecting is a valuable tool used to find agents with potential for industrial process.

With the biotechnology progress yeast strains may be selected by its desirable characteristics. The selection of suitable yeast for each kind of fermentation is an important strategy to ensure good fermentation and process yield. In Brazil the commercial production of ethanol for fuel uses the yeast Saccharomyces cerevisiae as agent, in granular form or in pressed humid tablets.

The inoculation allows establishing a high population of a selected strain of yeasts in order to ensure their dominance in the process, resulting in a fast fermentation and high alcohol production (Dorneles et al., 2005).

Although a new front is opening up for sugar and ethanol industry in Brazilian Midwest, little research has been done towards search for specialized agents adjusted to the environmental conditions of the region. To support the implementation of ethanol sector in this region, the selection of more suitable agents is crucial, since weather conditions can cause stress of commercial yeasts strains and interfere in the fermentation performance.

During the fermentation process is common the occurrence of wild yeast comes from the sugar cane juice and the environment. Since the conditions in the industries lack of asepsis it favors the predominance of wild yeast in the fermentation, replacing the inoculated yeast (Ceccato-Antonin et al., 2004).

Author for correspondence: cereda@ucdb.br 
This wild yeast makes the bioprospecting an advantageous tool to obtain strains with potential for use in alcohol fermentation. The inoculum using native strains with fermentative capacity is an alternative for solving the problems of contamination by yeast with low fermentative capacity and avoids costly reductions in alcohol yield (Andrietta et al., 1995).

The fermentative capacity and power of dominance in the fermentation are both basic prerequisites for select yeasts to be used in fermentation processes of ethanol production (Silva Filho, 2004).

Pataro et. al. (2000), reports that most of the yeasts isolated from the fermentation processes are physiologically adapted to the conditions in that they are founded. However, it is possible that this characteristic may differ for yeasts founded in early or late stages of the fermentation.

Cabrini and Gallo (1999), isolated yeasts from the Pedra sugar mill with an alcohol distillery (Serrana, São Paulo State) from samples of sugar cane juice, centrifuged suspension of yeast and wine. The authors identified 72 yeasts belonging to five genera. The species Saccharomyces cerevisiae was the predominant yeast in this industry and the genus Saccharomyces had highest incidence.

This wild yeast is considered contaminants of the process. In a distillery in São Paulo State a strain of Saccharomyces cerevisiae was isolated from a continuous fermentation process. It was founded as the responsible for $10 \%$ reduction in fermentation yield and $18 \%$ in ethanol production. The authors point out that not always those wild yeasts are harmful. Sometimes strains are unnoted because it are compatible with the inoculated yeast or even more resistant to adverse conditions of the medium that the commercial ones (Parazzi and Oliveira, 1996).

After the isolation, the preservation of the available microorganisms is of fundamental importance in the prospective studies. Among the preservation methods, the most commonly used is the continuous ringing, water conservation, preservation in mineral oil, freezing at $-20{ }^{\circ} \mathrm{C}$, cryopreservation in liquid nitrogen and lyophilization. According to Borba (2000), the selection of appropriate methods for maintenance of fungi is based on phenotypic characteristics inherent to each, as well as the behavior of each species in relation to the methods of preservation.

Lyophilization as method for yeast preserving provides high death rate, but the survival viable cells remain stable during the storage period (Costa and Ferreira, 1991; Silva et al., 1992). Freeze drying is one of the most efficient methods for obtaining the conservation for extended periods of time. This efficiency is due to the removal of intracellular water by sublimation that prevent ice crystals formation, which damage the enzymes located in the cytosol of the cell (Costa and Ferreira, 1991).

If diversity of fermentative yeasts in the state of Sao Paulo is explored and commercialized, on the contrary the knowledge about wild yeasts in Mato Grosso is scarce. To reduce the differences and make the sector more competitive, it is important to isolate strains appropriated to the local weather conditions.

With this objective it was performed the isolation and morphological characterization of strains of wild fermentative yeast from sugar cane juice of a sugar mill with attached distillery from Barra do Bugres state of Mato Grosso, Brazil.

\section{MATERIAL AND METHODS}

The sugar mill with attached distillery is located at the city of Barra do Bugres, Mato Grosso, on $15^{\circ} 04^{\prime} 21$ south latitude and $57^{\circ} 10^{\prime} 52^{\prime \prime}$ west longitude and $171 \mathrm{~km}$ of the Capital Cuiaba. The industry produces alcohol, sugar, electrical energy and biodiesel, justifying the harvest period from March to early December.

Available sugar cane was a mixture of varieties SP79-1011, RB 86-7515 RB 75-5113, SP 835073, SP-8642 and RB 92-8064. Sample were collected for yeast selection during all the harvest period, bimonthly from December 2009 to November 2010, covering the hot and humid season (September, November, December and March) and the dry and cold season (May, July). The data of temperature and relative humidity in all the sampling period was provided by the agricultural sector of the same industry.

\section{Collection and plating}

The sugar cane juice was collected in sterilized flakes and the samples transported at low 
temperature to the Microbiology Laboratory of the State University of Mato Grosso (UNEMAT) located near $4 \mathrm{~km}$ from the industry. The culture medium used for isolation Saccharomyces to develop. The formulation is $2.0 \mathrm{~g}$ of malt extract, $4.0 \mathrm{~g}$ of yeast extract, $2.0 \mathrm{~g}$ peptone, $1.0 \mathrm{~g}$ glucose, $1.0 \mathrm{~g}$ potassium phosphate dibasic, $0.5 \mathrm{~g}$ of ammonium chloride, $20.0 \mathrm{~g}$ agar, $6 \mathrm{mg}$ of crystal violet solution, $0.1 \mathrm{~g}$ of fuchsin-sulfite mixture, $5 \mathrm{mg}$ of nalidixic acid solution and 50mg of ampicillin solution. The formula of culture medium described by (Ceccato-Antonini et al., 2004) was adapt by adding ampicillin $(500 \mathrm{mg} / 1)$ to inhibit bacterial growth as described by (Silva and Cereda, 2009).

The sugar cane juice collected was serially diluted in saline $(0.85 \%)$ up $10^{-10}$. Petri dishes containing modified LWYN were inoculated with $0.1 \mathrm{ml}$ of each dilution, spread with a Drigaslky handle. The plates were incubated at $30{ }^{\circ} \mathrm{C}$ for 48 to 72 hours (APHA, 2001).

\section{Isolation and purification of colonies}

After the incubation period colonies were selected from those plates showing the better distribution. A colony from each morphotypes was isolated, suspended in $2.0 \mathrm{ml}$ saline $(0.85 \%)$ and plated on medium LWYN by at least twice for confirmation of culture purity.

\section{Morphological characterization}

The purified colonies were described in relation to morphological features such as edge, color, texture and shine.

\section{Fermentation test}

Al colonies of wild yeasts isolated as morphotypes were evaluated for ethanol fermentation. The same sugar cane juice was adjusted to $12^{\circ}$ Brix with distilled water. A volume of $10.0 \mathrm{ml}$ of diluted sugar cane juice December and July presented the greater number and yeasts diversity, with 12 and 10 isolates respectively, near $50 \%$ showed a strong fermentation. The climate conditions only cannot explain the concentration of yeasts in these months. In September there was founded less diversity with a few yeasts considered as morphologically different. This month (Table 1) showed the lowest values of relative humidity $(18 \%)$ and higher temperature $\left(42^{\circ} \mathrm{C}\right)$. From the and morphological characterization was the Lin Wild Yeast Medium (LWYN) described as a differential medium, allowing only the wild yeast of the genus was transferred for test tubes containing an inverted Durham tube. The set was autoclaved $120^{\circ} \mathrm{C}$ per 20 minutes. Dilutions were made for each morphotypes using saline solution tubes and two heave taken as way to provide cell concentration corresponding near to the scale 5.0 Mac Farland. Tubes in triplicate were incubated at $30{ }^{\circ} \mathrm{C}$ for 72 hours. The criterion for selection of yeast as fermentative was the turbidity of the medium and production and gas retention in Durham tube.

\section{Maintenance of yeast}

Only morphotypes with positive evaluation for fermentation were received letters as identification and were kept under refrigeration $\left(4{ }^{\circ} \mathrm{C}\right)$ in inclined tubes with sterile PDA medium until its reactivation for further analysis.

\section{Preservation of yeasts}

The evaluated yeasts were preserved by lyophilization (Costa and Ferreira, 1991) by suspending the yeasts from PDA inclined tubes in $3 \mathrm{ml}$ of $10 \%$ (w/v) skimmed milk Lakbom, put in Ependorffs tubes placed in a ultra freezer for thirty minutes and freeze-dried in a Biotop Biobrás model $101 \mathrm{~L}$ for eight hours.

\section{RESULTS AND DISCUSSION}

From 28 morphotypes isolated only 16 presented fermentative metabolism. These were morphologically described and designated BB. 01 BB.16. Table 1 present the morphotypes, the months were they are collected and the local meteorological conditions.

colonies grew in the plates, only one was considered as a different morphotypes, but without fermentation ability. November provided isolation of several colonies with different morphotypes, however, only one was considered as a different morphotypes if compared to that had been isolated previously. 
Table 1. Morphotypes isolated from each period and the local meteorological conditions.

\begin{tabular}{|c|c|c|c|c|c|}
\hline \multirow[t]{2}{*}{ Months } & \multicolumn{2}{|c|}{$\begin{array}{l}\text { Number of } \\
\text { morphotypes }\end{array}$} & \multirow{2}{*}{$\begin{array}{c}\begin{array}{c}\text { Precipitation } \\
\text { Min - Max } \\
\text { Average }\end{array} \\
(\mathbf{m m})\end{array}$} & \multirow{2}{*}{$\begin{array}{c}\text { Temperature } \\
\text { Min - Max } \\
\text { Average }\end{array}$} & \multirow{2}{*}{$\begin{array}{c}\text { Air Humidity } \\
\text { AH (\%) }\end{array}$} \\
\hline & Isolates & Fermented & & & \\
\hline December / 2009 & $10_{\mathrm{C}}$ & $05_{\mathbf{B}}$ & $\begin{array}{c}1,0-49,0 \\
5,37_{\mathbf{C}}\end{array}$ & $\begin{array}{c}16,2-40,0 \\
27,5_{\mathrm{A}}\end{array}$ & $72_{\mathrm{A}}$ \\
\hline $\operatorname{March} / 2010$ & $01_{A}$ & $01_{A}$ & $\begin{array}{c}1,0-30,0 \\
5,26_{\mathrm{C}}\end{array}$ & $\begin{array}{c}22,2-39,7 \\
27,4_{\mathbf{A}}\end{array}$ & $68_{\mathrm{A}}$ \\
\hline May/2010 & $03_{\mathbf{A}}$ & $02_{\mathrm{A}}$ & $\begin{array}{c}2,0-48,0 \\
2,47_{\mathbf{B}}\end{array}$ & $\begin{array}{c}8,7-38,0 \\
24,8_{\mathbf{B}}\end{array}$ & $31_{\mathbf{B}}$ \\
\hline July/2010 & $12_{\mathrm{C}}$ & $07_{\text {B }}$ & $\begin{array}{c}0,0-8,40 \\
0,27_{\mathbf{B}}\end{array}$ & $\begin{array}{c}9,9-39,2 \\
24,2 \text { в }\end{array}$ & $28_{\text {B }}$ \\
\hline September 2010 & $01_{A}$ & $00_{\mathrm{A}}$ & $\begin{array}{c}0,0-0,0 \\
0,00_{\mathrm{A}}\end{array}$ & $\begin{array}{c}16,2-42,6 \\
29,5_{\mathrm{A}}\end{array}$ & $18_{\mathbf{B}}$ \\
\hline Novembro/2010 & $01_{A}$ & $01_{\mathrm{A}}$ & $\begin{array}{c}1,0-100 \\
5,47_{\mathrm{C}} \\
\end{array}$ & $\begin{array}{c}19,4-38,7 \\
27,3_{\mathrm{A}}\end{array}$ & $73_{\mathrm{A}}$ \\
\hline
\end{tabular}

Numbers followed by the same letters in column do not differ by Tukey test at $5 \%$ probability.

Table 2. Morphological characterization of yeasts colonies cultivated in Lin Wild Yeast Medium(LWYN) incubated at $30^{\circ} \mathrm{C}$ for 72 hours.

\begin{tabular}{cccccc}
\hline Strains & Diameter & Texture & Color & Surface & Board \\
\hline BB. 01 & $1-7 \mathrm{~mm}$ & Rough & Cream & Flat & Irregular \\
BB. 02 & $1-5 \mathrm{~mm}$ & Rough & Cream & Flat & Irregular \\
BB. 03 & $1-5 \mathrm{~mm}$ & Rough & Cream & Flat & Irregular \\
BB. 04 & $1-5 \mathrm{~mm}$ & Smooth & White & Convex & Regular \\
BB. 05 & $1-3 \mathrm{~mm}$ & Smooth & Cream & Convex & Regular \\
BB. 06 & $1-3 \mathrm{~mm}$ & Smooth & Pink & Convex & Regular \\
BB. 07 & $1-5 \mathrm{~mm}$ & smooth & Pink & Convex & Regular \\
BB. 08 & $1-2 \mathrm{~mm}$ & smooth & Cream & Convex & Regular \\
BB. 09 & $1-3 \mathrm{~mm}$ & smooth & Cream & Convex & Regular \\
BB. 10 & $2-4 \mathrm{~mm}$ & smooth & White & Convex & Regular \\
BB. 11 & $2-3 \mathrm{~mm}$ & smooth & Cream & Convex & Regular \\
BB. 12 & $2-3 \mathrm{~mm}$ & smooth & Cream & Convex & Regular \\
BB. 13 & $2-3 \mathrm{~mm}$ & smooth & Cream & Convex & Regular \\
BB. 14 & $1-3 \mathrm{~mm}$ & smooth & Cream & Convex & Regular \\
BB. 15 & $2-3 \mathrm{~mm}$ & smooth & Cream & Convex & Regular \\
BB. 16 & $2-3 \mathrm{~mm}$ & smooth & Cream & Convex & Regular \\
\hline
\end{tabular}

It is well reported that the medium and cultivation conditions may influence the morphological characteristics of colonies as size, shape of lips, color or surface texture. As all morphotypes were cultured in the same medium and conditions, the comparison is possible.

Table 2 presents the description of yeasts colonies with fermentative activity. Figure 1 illustrates some of the morphological types of colonies.
From the characterized colonies $18.7 \%$ showed irregular edges, flat and wrinkled texture.

The medium used may have influenced the color of the colonies, making difficult to differentiate the colonies. The major of the colonies $(75 \%)$ presented cream color, $12.5 \%$ a white color, and $12.5 \%$ slightly pink. The diameter of colonies ranged from 1 to $7 \mathrm{~mm}$.

The large majority (81.3\%) had regular edges, convex surface and smooth texture. These results agree with those obtained in the yeasts 
isolation from 46 sugar mill in Sao Paulo State in the harvests 2002, 2003 and 2004. In this bioprospecting of 300 wild yeast identified by karyotyping, 57\% showed colonies with regular edges, while $43 \%$ had irregular borders (Fermentec News, 2005).

Morphological characterization is an important tool for classic identification of yeasts.

Cid et al. (1994), has analyzed different strains and observed changes for different phenotypes as a consequence of morphological differences. Similarly the same authors isolated and characterized morphologically 10 strains of wild yeast from four sugar cane liquor (cachaça) distilleries in Jaboticabal, São Paulo State. All yeast strains presented convex colonies with smooth texture. The color ranged from white to pink colonies and the diameter of 1-3 mm. It was observed different growth behavior as consequence of different mediums used in the identification of the yeasts.

The characterization of yeast is very important to found similarities and differences between the microorganisms. In an environment with high biodiversity as the found in the alcoholic fermentation in which many organisms may live together, the knowledge of the physiological and morphological characteristics may help to choice methods and techniques for control or stimulate the yeast in the process (CeccatoAntonini, 2010).

\section{CONCLUSIONS}

It was concluded that bioprospecting of sugar cane juice is potentially a suitable tool for select fermentative yeasts. Sixteen morphotypes was selected by its ability to ferment. The mouths of December and July were the best for bioprospecting and presented the high number of different colonies. This result was not explained only by the weather conditions. In the best period it was isolated $56.2 \%$ of the yeasts with worm temperature with high humidity but the second one $(43.8 \%)$ presented a wet season (November to March). The yeasts showed similar morphological features and the most frequent colonies were smooth, shiny, with a convex surface and regular edges.

\section{ACKNOWLEDGEMENTS}

The authors thank the plant Barrálcool for cooperation in research and stock provided; To undergraduate students of Food Engineering of UNEMAT - Marcel, Deborah, Gracie, and Laide Stéfanie - for his help with laboratory activities.

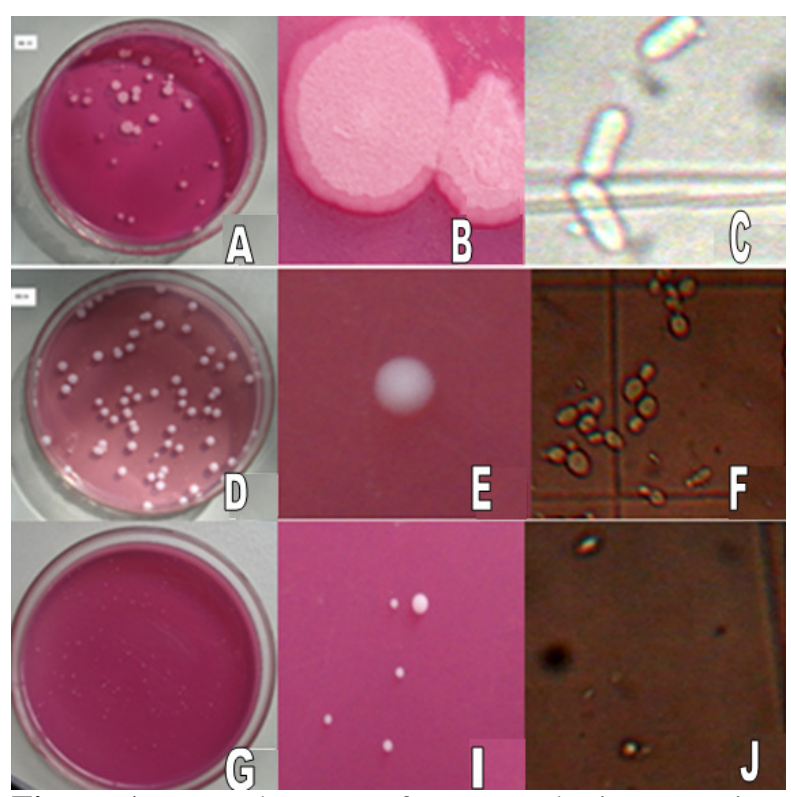

Figure 1 - Morphotypes of yeasts colonies grew in LWYN for 72 hours at $30^{\circ} \mathrm{C}$ for yeast BB 01 (A), BB 04 (D) and BB $05(\mathrm{G})$, details of colonies (B, E, $\mathrm{H})$ and cells $(\mathrm{C}, \mathrm{F}, \mathrm{I})$.

\section{RESUMO}

A produção de etanol é importante para a economia nacional constituindo-se em solução renovável para complementar derivados de petróleo. O processo industrial utiliza leveduras disponíveis comercialmente, a maioria das quais isoladas em usinas do estado de S. Paulo. Não se têm conhecimento sobre a disponibilidade de leveduras selecionadas para as condições climáticas da região Centro Oeste. O artigo apresenta os resultados do isolamento e caracterização morfológica de leveduras selvagens fermentativas obtidas do caldo de cana da usina do município de Barra do Bugres, Mato Grosso. As amostras de caldo foram coletadas na época quente e chuvosa e na fria e seca da mesma safra. Foram semeadas em agar LWYN e avaliadas para fermentação em tubos de ensaio contendo tubos de Durhan invertidos. Apenas aquelas com habilidade para fermentar percebidas pela presença de bolhas de gás foram caracterizadas. Maior número e diversidade de leveduras foram obtidas nos meses de dezembro e julho, mas, apenas as condições climáticas não explicaram esses resultados. Concluiuse que o caldo de cana é uma boa fonte para biodiversidade em leveduras.

Palavras-chave: Isolamento, morfologia, bioprospecção, biodiversidade, fermentação 


\section{REFERENCES}

Andrietta, S. R.; Andrietta, M. G. S.; Rodrigues, M. I. (1995), Método de caracterização de leveduras de processo utilizando parâmetros cinéticos e produção específica. Stab/Açúcar, Álcool e Subprodutos, 4, 22-25.

APHA, American Public Health Association. (2001), Compendium of methods for the microbiological examination of foods. 4.ed. Washington, 64p.

Borba, C. M. and Rodrigues, K. F. (2000), Viability and sporulating capability of Coelomycetes preserved under a range of different storage regimes. Revista Iberoamericana de Micología, 17, 142-145.

Cabrini, K. T. and Gallo, C. R. (1999), Identificação de leveduras no processo industrial de fermentação alcoólica em usina do Estado de São Paulo, Brasil. Scientia Agricola, 1, 207-216.

Ceccato- Antonini, S. R.; Tosta, C. D.; Silva, A. C. (2004), Determination of yeast killer activity in fermenting sugarcane juice using selected ethanol-making strains. Brazilian Archives of Biology and Technology, 1, 13-23.

Ceccato-Antonini, S. R. (2010), Microbiologia da fermentação alcoólica. A importância do monitoramento microbiológico em destilarias. São Carlos: EduFSCar, 1, 105p.

Cid, V. J.; Sanchez, M.; Nombela, C. (1994), Characterization of thermosensitive autolytic mutants from diploid, Saccharomyces cerevisiae. Microbiology, 140, 559-68.

Costa, C. P.; Ferreira, M. C. (1991), Preservação de micro-organismos. Revista de Microbiologia, 3, 263-268.

Dorneles, D.; Machado, I. M. P.; Chociai, M. B.; Bonfim, T. M. B. (2005), Influence of the use of selected and non-selected yeasts in red wine production. Brazilian Archives of Biology and Technology. 48, 747-751.
Fermentec News, Disponível em: $<$ http://www.fermentec.com.br/br/news/Ferment ec\%20News\%2002\%20\%202005.pdf> acesso em 28/01/2010.

Pataro, C.; Guerra, J. B.; Petrilho, P. M. L, Mendonça, H. Lc, Linardi, V. R.; Rosa, C. A. (2000), Yeast communities and genetic polymorphism of Saccharomyces cerevisiae strains associated with artisanal fermentation in Brazil. Journal of Applied Microbiology, 1, 2431.

Parrazi, C. and Oliveira, M. C. F. L. (1996), Comparação de linhagens de leveduras Saccharomyces cerevisiae floculantes em processo descontínuo de produção de álcool e aguardente In: Congresso Nacional da Stab, Anais, 1, 121-129.

Pelczar Jr, M. J.; Chan,E. C. S.; Krieg, N. R. (1996), Microbiologia: conceitos e aplicações. 2 ed. São Paulo: Makron Books do Brasil. 1, 524p.

Silva Filho, E. A. Caracterização genética de populações de leveduras de destilarias de álcool combustivel para otimização do processo de fermentação. Tese (Doutorado em Biologia de Fungos) - Universidade Federal de Pernambuco, 2004.

Silva, L.; Ferreira, D.; Kamiya, N. F; Oliveira, M. S; Alterthum, F. (1992), Comparison of preservation methods applied to yeasts used for ethanol production in Brazil. Revista de Microbiologia, 3, 177-182.

Silva, C. V. F and Cereda, M. P. (2009), Isolamento de Leveduras Selvagens resistentes a radiação Ultravioleta do Caldo Fermentado de cana de açúcar (Sacharum officinarum) da cultivar RB-7515. CeTeAgro - Centro de Tecnologia e Análise para o Agronegócio. Universidade Católica de Campo Grande-MS. 